\title{
Antibiotic resistance of heterotrophic bacteria in Shira lake: natural and anthropogenic impacts
}

\author{
T. I. Lobova*, Yu. V. Barkhatov, L. Yu. Popova
}

Centre Institute of Biophysics, Russian Academy of Sciences, Siberian Branch, Academgorodok 50, Krasnoyarsk 660036, Russia

\begin{abstract}
Studies were conducted to investigate the antibiotic resistance of freshwater, halophile and moderate halotolerant bacteria isolated from the nearshore part of Shira lake, which is affected by the activity of a health resort, and from the central part of the lake in the summer (June to August) of 1999. It has been shown that the allochthonous microflora, which is brought into the lake with the resort effluent in mid-summer, is the anthropogenic factor contributing to an increase in the number of freshwater bacteria that feature multiple antibiotic resistance in the central part of the lake. It has been found that resistance to ampicillin of freshwater and halophile heterotrophic bacteria is related to the increase in the biomass of blue-green and green algae in the central part of Shira lake between mid-July and the end of August. A mathematical model has been constructed to describe the dynamics of the antibiotic resistance of heterotrophic bacteria in the close-to-resort and the central parts of Shira lake under natural and anthropogenic impacts.
\end{abstract}

KEY WORDS: Heterotrophic bacteria $\cdot$ Halotolerance $\cdot$ Antibiotic resistance $\cdot$ Anthropogenic load · Brackish lake $\cdot$ Mathematical modeling

Resale or republication not permitted without written consent of the publisher

\section{INTRODUCTION}

One of the current tasks ecology must cope with is to assess the anthropogenic impact on natural ecosystems, and to preserve these ecosystems (Lenski 1998, Hound et al. 2000, Lemke \& Leff 2000, McArthur \& Tuckfield 2000, Yang et al. 2000). The greatest emphasis is placed on the ecosystems that feature therapeutic properties and, thus, are of particular significance to humans (Parnacher \& Vishnivetsky 1997). An example of such an ecosystem is Shira lake-a brackish lake in East Siberia, Russia.

Shira lake features unique therapeutic properties, which are largely determined by the specific chemical composition of the water. The Shira lake water has high levels of sulfate, chloride, hydrocarbonate, sodium and magnesium. It is alkaline and contains up to $22 \mathrm{~g} \mathrm{l}^{-1}$ of dissolved salts. The water also contains trace elements such as copper, strontium, lithium, aluminum, iron and uranium. The mineral water of

*Email: lubg@ibp.krasnoyarsk.su
Shira lake is used to treat chronic diseases of the stomach, the gall-bladder, the cardio-vascular system, the skeleton and muscles, and other organs (Kurlov 1927). The heterotrophic microflora of the lake is represented by groups of bacteria varying in halotolerance. Besides the freshwater bacteria (unable to tolerate more than $3 \% \mathrm{NaCl}$ ), which predominate in the lake, there are also halophilic bacteria (capable of growing in the medium containing 0.05 to $5 \% \mathrm{NaCl}$ ) and moderate halotolerant bacteria (able to tolerate 0.05 to $15 \% \mathrm{NaCl}$ ) (Boyandin et al. 2000). There has been a health resort on the shore of the lake for over 100 yr. In the last 2 decades, however, anthropogenic impacts have caused deterioration of the natural condition of all the lake components. For example, the ecosystem annually receives up to 1 million $\mathrm{m}^{3}$ of unprocessed resort effluents containing human and animal microflora. As a result, both the chemical composition of the water and its bacteriological parameters change. The Son River (the only river flowing into the lake, which has no outflow) supplies the lake with organic and mineral substances as well as with allochthonous microflora from livestock farms located 
upstream (Parnachev 1997). The result of all these processes may be a disturbance of the natural biodiversity of Shira lake.

There are various ways to estimate the anthropogenic load on an ecosystem, including chemical analysis, bioindication, bioassays, etc. (Doust et al. 1994, Ostroumov 2000, Lindstron-Seppa et al. 2001, Samecka-Cymerman \& Kempers 2001). Bacteria are often used to monitor the state of the environment (Jacobs et al. 1995, Schwedt et al. 1997, Backhaus \& Grimme 1999), as their evolution rate is very high, and under the effect of environmental factors they can acquire various specific features, and thus, serve as good indicators for the presence of pollutants. One of the properties of bacteria used to assess the anthropogenic load is their antibiotic resistance (Hagedorn et al. 1999, Goni-Urriza et al. 2000, Mary et al. 2000, McArthur \& Tuckfield 2000).

Antibiotic resistance in bacteria can be determined both by chromosome genes and by extrachromosome genetic elements (R-plasmids) (Gomes-Lus 1998, Ho et al. 1998). The acquisition of antibiotic resistance is realized as an active process only under the conditions selective for such genes (Chandrasekaran et al. 1998, Guardabassi et al. 1998, Goni-Urriza et al. 2000). Thus, if antibiotic resistance is recorded in a great number of heterotrophic bacteria, a drastic change in the environmental conditions due to direct or indirect impact of non-natural factors may be assumed.

The aim of this work is to investigate the dynamics of antibiotic resistance of heterotrophic bacteria varying in halotolerance in the central and the close-to-resort parts of Shira lake. In addition, we determine the relationship between antibiotic resistance of microorganisms and anthropogenic and natural impacts.

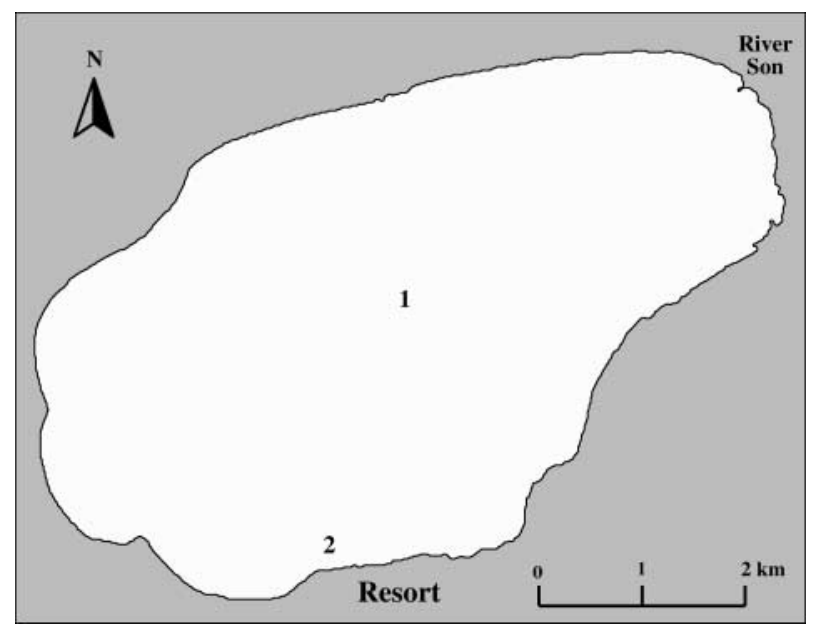

Fig. 1. Sampling sites (Stns 1 and 2) in Shira lake, Khakasia Republic, Russia

\section{MATERIALS AND METHODS}

Sampling site and procedure. Shira lake is a brackish lake in the south of the Khakasia Republic, Russia $\left(90^{\circ} 14^{\prime} \mathrm{E}, 54^{\circ} 30^{\prime} \mathrm{N}\right)$. The lake is $9.35 \mathrm{~km} \mathrm{long}$ and $5.3 \mathrm{~km}$ wide, and has no outflow. The Son, a freshwater river, flows into the lake from the east and contributes $42 \%$ of the lake water resource. The Shira lake water has high levels of sulfate, chloride, hydrocarbonate, sodium and magnesium. It is alkaline and contains up to $22 \mathrm{~g} \mathrm{l}^{-1}$ of dissolved salts.

Samples from Shira lake were taken from 2 locations with a Molchanov sampler (two 21 bottles) (Fig. 1): (1) Stn 1 in the central part, $2000 \mathrm{~m}$ away from the resort and $21 \mathrm{~m}$ deep; and (2) Stn 2 in the southwest of the lake (close to the resort), $80 \mathrm{~m}$ away from the shore and $2.3 \mathrm{~m}$ deep.

Sampling at the stations was conducted throughout the summer of 1999 (in June, July and August), every 7 to $10 \mathrm{~d}$. Samples in the central part of the lake (at Stn 1) were collected from the surface layer of the epilimnion at a depth of 0.5, 10 (the metalimnion) and $20 \mathrm{~m}$ (the hypolimnion). Water samples from Stn 2 were collected at $0.5 \mathrm{~m}$

The water at the study locations is of the same chemical composition but contains different amounts of sodium chloride: $2.7 \mathrm{~g} \mathrm{l}^{-1}$ near the resort, and $1 \mathrm{~g} \mathrm{l}^{-1}$ (0.5 m depth), 3.7 to $4 \mathrm{~g} \mathrm{l}^{-1}$ (10 $\mathrm{m}$ depth) and 4 to $5 \mathrm{~g} \mathrm{l}^{-1}$ (21 $\mathrm{m}$ depth) in the central part of the lake. During summer, the central part of the lake is density stratified. In the epilimnion, the water is warmer (15 to $25^{\circ} \mathrm{C}$ ), while the hypolimnion water is at a lower temperature $\left(1.2\right.$ to $\left.1.3^{\circ} \mathrm{C}\right)$ and features a higher salinity (21 to $22 \mathrm{~g} \mathrm{l}^{-1}$ ). The thermocline is at a depth of 6 to $8 \mathrm{~m}$. The highest oxygen content is recorded in the 8 to $9 \mathrm{~m}$ deep water layer. The layer at 12 to $14 \mathrm{~m}$ is an aerophilous zone, in which both oxygen and hydrogen sulfide are present. Here, a sharp gradient of the redox potential (Eh), or chemocline, is observed. The physicochemical parameters of the Shira lake water are described in greater detail in Kalacheva et al. (2002).

The investigations were carried out at the Institute of Biophysics SB RAS's field station 'Shira lake'.

Media. Water samples were plated on mineral medium (M9) that contained $6 \mathrm{~g} \mathrm{Na}_{2} \mathrm{HPO}_{4} \mathrm{l}^{-1}, 3 \mathrm{~g}$

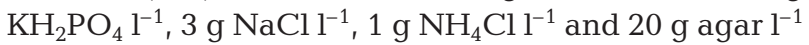
distilled water. After autoclaving, $1 \mathrm{ml} 20 \% \mathrm{MgSO}_{4}, 1 \mathrm{ml}$ $0.5 \% \mathrm{CaCl}_{2}$ and $10 \mathrm{ml} 20 \%$ glucose were added (Miller 1972). Enriched media contained $5 \mathrm{~g}$ peptone $\mathrm{l}^{-1}$. To isolate halotolerant bacteria, 0.5 to $200 \mathrm{~g} \mathrm{NaCl}^{-1}$ were added to the M9 medium. Antibiotics were added to the solid media at a concentration of $50 \mu \mathrm{g} \mathrm{ml}^{-1}$. The investigation involved antibiotics used widely in the medical practice: ampicillin (an inhibitor of the cell wall synthesis) and kanamycin (an inhibitor of protein synthesis). 
Heterotrophic bacteria. To determine colony forming units $(\mathrm{CFU})$, water samples were plated on agar (Sommaruga \& Conde 1997, Bernard et al. 2000) and cultivated for $7 \mathrm{~d}$ at $25^{\circ} \mathrm{C}$ (Simon et al. 1999, Zhongtang et al. 2000).

The halotolerance of bacteria was determined by plating on $\mathrm{M} 9$ media with different $\mathrm{NaCl}$ contents (Miller 1972). The objects of the investigation were 3 groups of heterotrophic bacteria differing in their resistance to osmotic pressure: freshwater bacteria (unable to tolerate more than $3 \% \mathrm{NaCl}$ ), halophile bacteria (able to tolerate 0.05 to $5 \% \mathrm{NaCl}$ ) and moderate halotolerant bacteria (able to tolerate 0.05 to $10 \% \mathrm{NaCl}$ ).

The antibiotic resistance of bacteria was tested on solid media amended with different antibiotics (Miller 1972). The antibiotic resistance of heterotrophic bacteria was estimated by the number of: (1) bacteria resistant to ampicillin; (2) bacteria resistant to kanamycin; (3) bacteria resistant to both ampicillin and kanamycin; and (4) bacteria sensitive to ampicillin and kanamycin. The number of bacteria sensitive to ampicillin and kanamycin was determined from the number of bacteria unable to grow on the antibiotic-containing medium.

The biomass of each morphological group of bacteria (of the same size and shape) was determined by multiplying the CFU by the cell volume. The total biomass was determined by adding up all the cultured morphological groups of bacteria.

Table 1. Antibiotic resistance of heterotrophic bacteria from Shira lake during summer 1999. Apr: bacteria resistant to ampicillin; Kmr: bacteria resistant to kanamycin; AprKmr: bacteria resistant to both ampicillin and kanamycin; ApsKms: bacteria sensitive to ampicillin and kanamycin

\begin{tabular}{|c|c|c|c|c|}
\hline \multicolumn{2}{|c|}{$\begin{array}{l}\text { Sampling site (depth) } \\
\text { Sampling } \\
\text { period }\end{array}$} & \multicolumn{3}{|c|}{$\begin{array}{l}\text { Bacterial biomass with } \\
\text { different resistance forms } \\
\text { to antibiotics }\left(\mathrm{mg} \mathrm{m}^{-1}\right)\end{array}$} \\
\hline & Apr & $\mathrm{Kmr}$ & AprKmr & ApsKms \\
\hline \multicolumn{5}{|c|}{ Resort $(0.1 \mathrm{~m})$} \\
\hline Jun & 0 & 0 & 0 & $8.00 \mathrm{E}-10$ \\
\hline Jul & $2.73 E-06$ & 8.80E-08 & 4.33E-05 & 4.92E-07 \\
\hline Aug & $2.59 \mathrm{E}-08$ & $1.42 \mathrm{E}-10$ & $1.42 \mathrm{E}-07$ & $2.84 \mathrm{E}-10$ \\
\hline \multicolumn{5}{|c|}{ Center $(0.5 \mathrm{~m})$} \\
\hline Jun & $3.60 \mathrm{E}-09$ & 0 & 0 & $1 \mathrm{E}-08$ \\
\hline Jul & $1.15 \mathrm{E}-08$ & 8.82E-10 & $1.72 \mathrm{E}-09$ & 3.59E-06 \\
\hline Aug & $1.50 \mathrm{E}-06$ & $1.11 \mathrm{E}-08$ & $8.65 \mathrm{E}-07$ & $2.25 \mathrm{E}-06$ \\
\hline \multicolumn{5}{|c|}{ Center $(10 \mathrm{~m})$} \\
\hline Jun & $3.43 \mathrm{E}-10$ & 0 & $8.76 \mathrm{E}-08$ & $2.45 \mathrm{E}-07$ \\
\hline Jul & $4.51 \mathrm{E}-07$ & $1.25 \mathrm{E}-08$ & $2.91 \mathrm{E}-07$ & 8.72E-07 \\
\hline Aug & $1.64 \mathrm{E}-08$ & $2.16 \mathrm{E}-08$ & $2.55 \mathrm{E}-08$ & 9.73E-08 \\
\hline \multicolumn{5}{|l|}{ Center $(20 \mathrm{~m})$} \\
\hline Jun & $2.55 \mathrm{E}-09$ & 0 & $2.50 \mathrm{E}-09$ & $1.70 \mathrm{E}-08$ \\
\hline Jul & $4.36 \mathrm{E}-10$ & $7.84 \mathrm{E}-11$ & $8.09 \mathrm{E}-10$ & 1.72E-08 \\
\hline Aug & $1.76 \mathrm{E}-10$ & 4.32E-08 & 4.32E-06 & $7.80 \mathrm{E}-08$ \\
\hline
\end{tabular}

\section{RESULTS AND DISCUSSION}

The investigation of antibiotic resistance of heterotrophic bacteria isolated from the central and the closeto-resort parts of Shira lake showed that biomass of microorganisms featuring multiple antibiotic resistance sharply increased in the close-to-resort part of the lake in July 1999 (Table 1). Resistance of bacteria to ampicillin and kanamycin, which was recorded in that period, could be accounted for by anthropogenic impact, i.e. by the input of allochthonous microflora from the resort. This assumption was supported by investigations of the seasonal dynamics of antibiotic resistance exhibited by heterotrophic bacteria in Shira lake. It has been shown that in winter and in spring, when the resort is less frequented, the number of heterotrophic bacteria featuring multiple antibiotic resistance significantly decreases in the nearshore part of the lake. In summer (June, July, and August), the situation in the lake reverses, i.e. the number of microorganisms resistant to both ampicillin and kanamycin increases (Lobova et. al. 2001). In the cold season (winter and spring), bacteria sensitive to antibiotics predominate both in the central part of Shira lake and near the resort. In summer, the proportion of bacteria displaying multiple antibiotic resistance in the total number of the isolated cultured heterotrophic microorganisms increases in the central part of the lake (Lobova et. al. 2001). Thus, we assume that the varying levels of anthropogenic impact can account for the winter-summer variations in the proportions of bacteria sensitive to antibiotics, and of bacteria displaying multiple antibiotic resistance isolated both from the close-to-resort and the central parts of the lake. The most important factors contributing to the anthropogenic impacts are effluents from the summer resort and human and animal microflora.

The predominance of bacteria featuring multiple antibiotic resistance in the close-to-resort part of the lake may result in the emergence of multiple antibiotic resistance in the heterotrophic microorganisms found in the part of the lake not directly affected by the anthropogenic input (the center). The impact of the resort on the central part of the lake was estimated by comparing the antibiotic resistance of freshwater, halophile and moderate halotolerant heterotrophic bacteria from the close-to-resort and the central parts of Shira lake. In June, the freshwater and halophile heterotrophic bacteria found in the close-to-resort part of the lake were mostly represented by isolates sensitive to antibiotics. In July, the number of the freshwater and moderate halotolerant bacteria displaying multiple antibiotic resistance drastically increased. In August, the number of heterotrophic microorganisms in the close-to-resort part of Shira lake significantly 
decreased, and multiple antibiotic resistance was displayed by freshwater and halophile bacteria (Fig. 2 AI,BI,CI).

The presence of heterotrophic bacteria featuring multiple antibiotic resistance in the close-to-resort part of Shira lake may be due to 2 reasons. First, in July, the lake received allochthonous, largely freshwater microflora; hence, the number of microorganisms sharply increased in this period (Fig. 2). It is noteworthy that in cold seasons (winter and spring) the freshwater bacteria of the close-to-resort part of the lake display sensitivity to antibiotics. During this period, halophile bacteria, rather than freshwater ones, predominate in this part of the lake (Lobova et al. 2001). Thus, we think that in the close-to-resort part of Shira lake, the summer increase in the proportion of the freshwater bacteria resistant to ampicillin and kanamycin, with a simultaneous decrease in the proportion of halophile bacteria, must be due to the input of allochthonous microflora with genetic determinants of multiple antibiotic resistance. The second reason is that some factor present in the lake in July and August induces the selection of the cells resistant to ampicillin and kanamycin (Fig. 2).

The antibiotic resistance of moderate halotolerant heterotrophic bacteria must be related to their peculiar structure. The cell membrane of halotolerant bacteria contains proteins, which reduce its permeability and enhance the bacteria's resistance to various ambient factors (Ventoza et al. 1998). Moderate halotolerant bacteria predominate at depths of 10 and $20 \mathrm{~m}$ in the central part of the lake, where the $\mathrm{NaCl}$ concentration is the highest ( 21 to $22 \mathrm{~g} \mathrm{NaCl} \mathrm{l}^{-1}$ ). Moderate halotolerant bacteria can probably be moved to the close-toresort part of Shira lake $\left(2.4 \mathrm{~g} \mathrm{NaCl} \mathrm{l}^{-1}\right)$ from the central part in the process of water mixing.

In the central part of Shira lake, where microorganisms featured multiple antibiotic resistance, freshwater and halophile bacteria only displayed resistance to ampicillin, which was not recorded in microorganisms in the close-to-resort part of the lake (Fig. 2 AII,BII,CII). We have made an attempt to find possible reasons for resistance to antibiotics displayed by freshwater, halophile and moderate halotolerant bacteria in the central part of Shira lake. A drastic increase in the number of microorganisms featuring multiple antibiotic resistance both in the center of the lake and in the closeto-resort part recorded in July could be due to the passive migration of microflora from the resort to the center of the lake. Freshwater heterotrophic bacteria displayed the greatest increase in multiple antibiotic resistance, which distinguished them from halophile and moderate halotolerant microorganisms (Fig. 2 AII,BII,CII).

We suppose that resistance to ampicillin only, which is displayed by bacteria in the central part of Shira lake, is not related to anthropogenic impacts, because no ampicillin resistance has been recorded in bacteria of the close-to-resort part. In the central part, however, at a depth of $10 \mathrm{~m}$, the proportion of microorganisms resis-
A

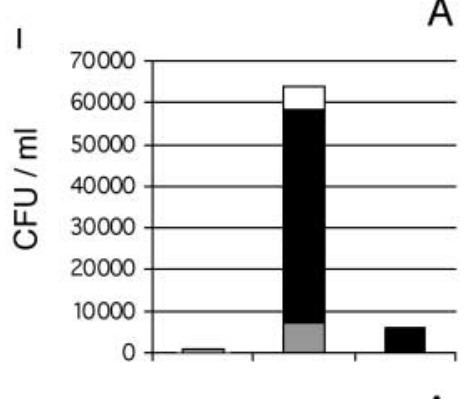

II

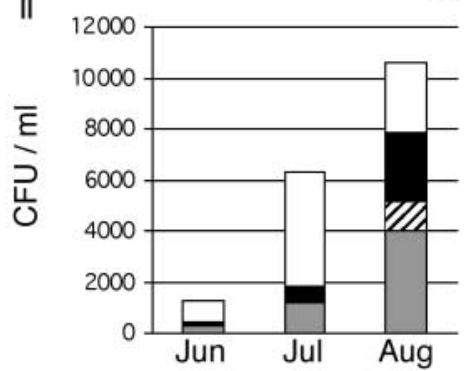

B

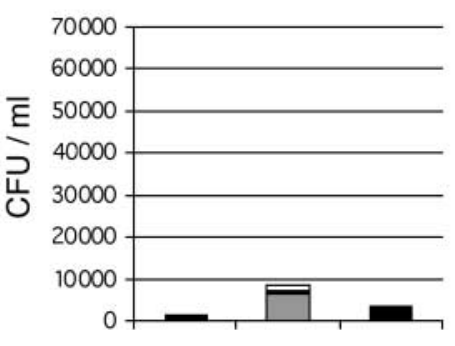

B

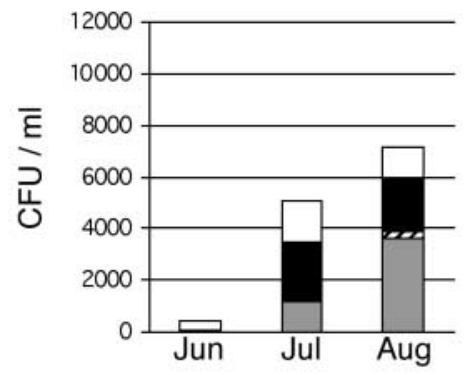

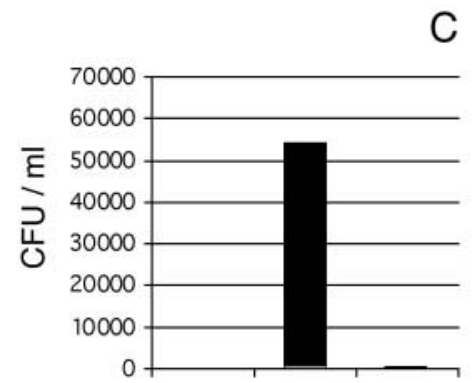

C

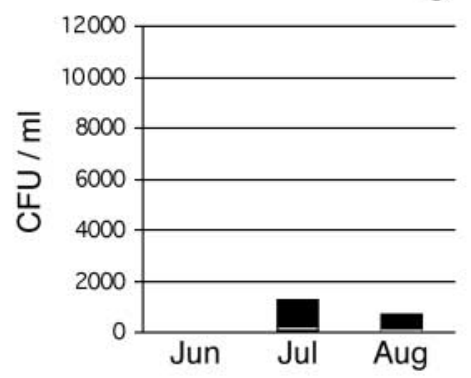

Fig. 2. Antibiotic resistance of freshwater, halophile and moderate halotolerant bacteria from the central and nearshore (close-toresort) parts of Shira lake for summer 1999: I-nearshore part of lake, II-central part of lake (average data); A-freshwater bacteria, B-halophile bacteria, C-moderate halotolerant bacteria; white bars — bacteria sensitive to antibiotic, black bars — bacteria with multiple antibiotic resistance, striped bars - bacteria resistance to kanamycin, gray bars — bacteria resistance to ampicillin 
tant to ampicillin in the groups of halophile and freshwater bacteria increases significantly in July and August (Fig. 3). The dynamics of the ampicillin resistance patterns in these 2 groups of bacteria are the same (Fig. 2 $\mathrm{AI}, \mathrm{BI})$. The obtained results suggest that in the center of the lake there is some factor inducing natural selection of the cells resistant to ampicillin and causing their predominance in populations of microorganisms.

Shira lake is inhabited by an extremely reduced number of organisms. Microalgae are among the most characteristic representatives of the lake biota, and blue-green and green algae predominate. Microalgae are distributed over depth in the central part of the lake, except in the lower layers (18 to $20 \mathrm{~m}$ ), and the maximum of their biomass is at a depth of 6 to $12 \mathrm{~m}$ (Zotina et al. 1999). The investigation of the vertical distribution of heterotrophic bacteria in Shira lake showed that in July, at depths of 0.5 and $10 \mathrm{~m}$, the number of microorganisms sharply increased (Lobova et al. 2000). At a depth of $10 \mathrm{~m}$, the proportion of the freshwater and halophile bacteria resistant to ampicillin became larger (Fig. 3). In August, the pattern was the same, but the most distinct ampicillin resistance was recorded in halophile heterotrophic bacteria. In the same period, ampicillin-resistant freshwater and halophile heterotrophic bacteria were recorded not only in the metalimnion but also in the surface layers of the lake. A possible reason may be passive migration of ampicillin-resistant bacteria from the deeper layers to the surface of the lake.

Thus, we assume that the dynamics of ampicillin resistance of freshwater and halophile heterotrophic bacteria in Shira lake is determined by the development of phytoplankton. In the course of their development, both blue-green and green algae release algal toxins possessing antimicrobial qualities (Doucette 1995). Blue-green and green algae of Shira lake may also release toxins, and this may be the reason for the selection of ampicillin resistant cells. This assumption has arisen from the revealed relationship between the ampicillin resistance of freshwater and halophile heterotrophic bacteria and phytoplankton biomass.

Therefore, the obtained experimental data allow an assumption that the distribution of the antibiotic-resistant heterotrophic bacteria varying in halotolerance in the central part of Shira lake depend on the origin of ambient factors. To verify our hypothesis, we have constructed a mathematical model of antibiotic resistance in the central part of the lake, based on the following assumptions: (1) the anthropogenic factor (allochtho-
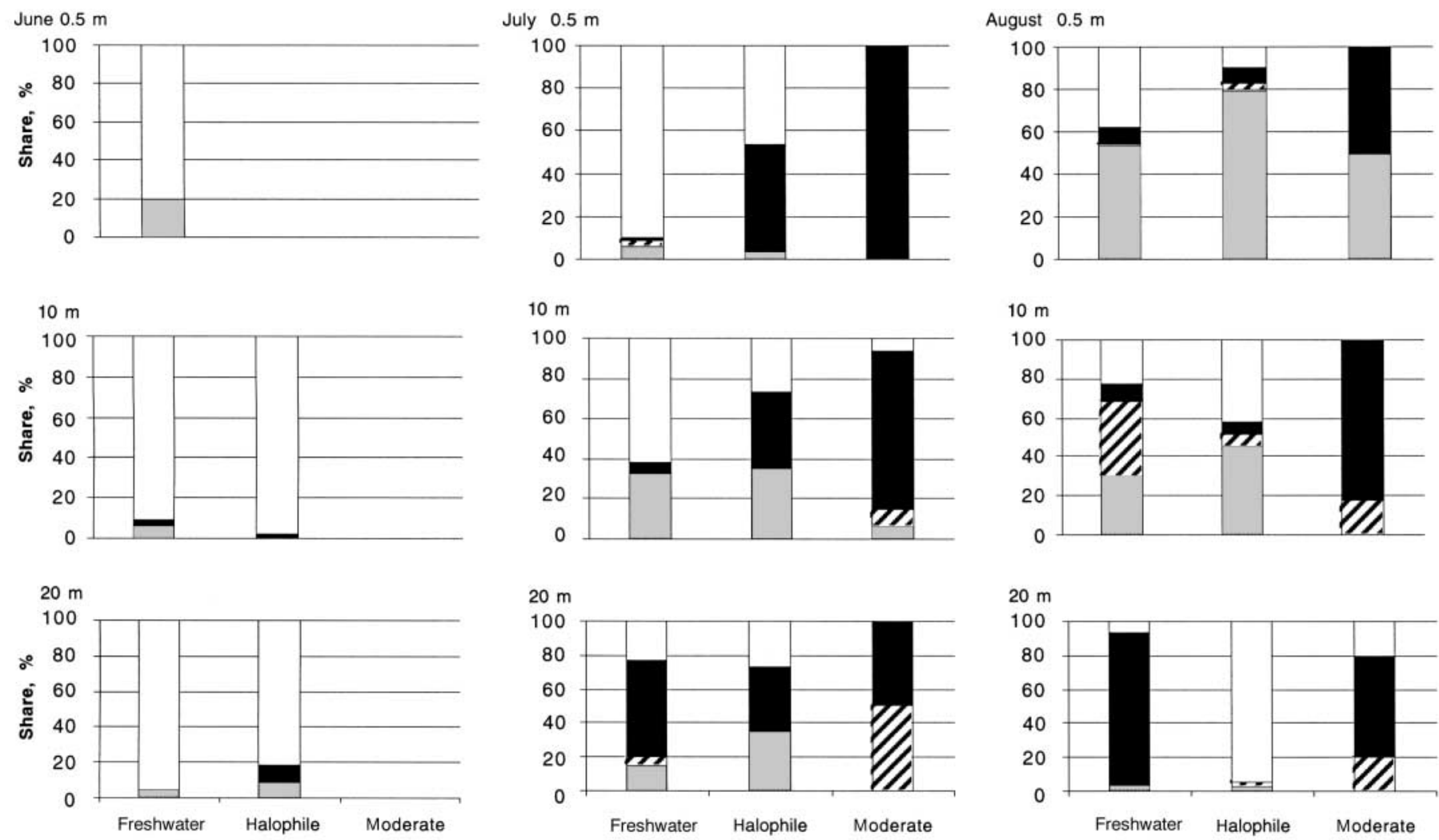

Fig. 3. Antibiotic resistance of freshwater, halophile and moderate halotolerant bacteria in the central part of Shira lake: white bars - bacteria sensitive to antibiotic, black bars — bacteria with multiple antibiotic resistance, striped bars - bacteria resistance to kanamycin, gray bars - bacteria resistance to ampicillin 


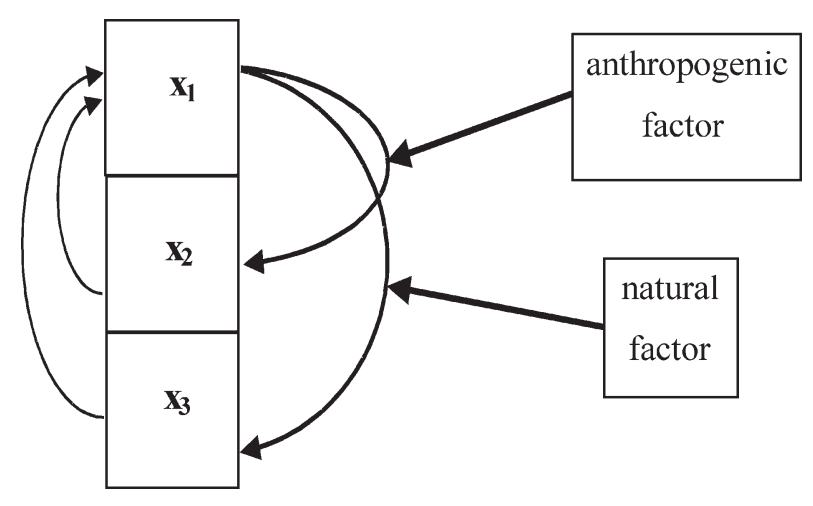

Fig. 4. Dynamics of antibiotic resistance of heterotrophic bacteria of Shira lake. $X_{1}$ : bacteria sensitive to antibiotics; $X_{2}$ : bacteria with multiple antibiotic resistance; $X_{3}$ : bacteria resistant to ampicillin

nous microflora) has a strong but short-term action; (2) the natural factor (toxin release by algae) has a constant action, which is weak at the beginning of summer, but gets stronger with time; and (3) the rate at which bacteria lose their antibiotic resistance is directly proportional to the bacterial growth rate.

A flow chart of the dynamics of multiple antibiotic resistance and ampicillin resistance in a certain group of bacteria in a certain part of a water body is given in Fig. 4. We assume that the given community of hetero- trophic bacteria is subdivided into 3 smaller ones, which differ in the type of antibiotic resistance. $X_{1}$ are bacteria sensitive to antibiotics $\left(\mathrm{ml}^{-1}\right) ; X_{2}$ are bacteria displaying multiple antibiotic resistance $\left(\mathrm{ml}^{-1}\right)$; and $X_{3}$ are bacteria resistant to ampicillin $\left(\mathrm{ml}^{-1}\right)$. The possible transfers between the communities are shown with arrows. A transfer from $X_{1}$ to $X_{2}$ is determined by the action of the anthropogenic factor, and a transfer from $X_{1}$ to $X_{3}$ is determined by the action of the natural factor. The loss of antibiotic resistance is also shown. The corresponding system of differential equations has the following form:

$$
\begin{aligned}
& \frac{\mathrm{d} X_{1}}{\mathrm{~d} t}=-F_{1} x_{1}-F_{2} x_{1}+\mu_{1} x_{1}-\varepsilon_{1} x_{1}+B_{1} x_{2}+B_{2} x_{3} \\
& \frac{\mathrm{d} X_{2}}{\mathrm{~d} t}=F_{1} x_{1}+\mu_{2} x_{2}-\varepsilon_{2} x_{2}-B_{1} x_{2} \\
& \frac{\mathrm{d} X_{3}}{\mathrm{~d} t}=F_{2} x_{1}+\mu_{3} x_{3}-\varepsilon_{3} x_{3}-B_{2} x_{3} \\
& F_{1}=\left\{\begin{array}{l}
0, \quad \text { if } t<t_{1} \\
k_{F_{1}} \text { if } t_{1}<t<t_{2} \\
0, \quad \text { if } t_{2}<t
\end{array}\right. \\
& F_{2}=A \frac{t}{t+C} \\
& B_{1}=b_{1}\left(\mu_{2}-\varepsilon_{2}\right) \\
& B_{2}=b_{2}\left(\mu_{3}-\varepsilon_{3}\right) \\
& \mu_{1}=\mu_{2}=\mu_{3}=\mu(t)
\end{aligned}
$$

A

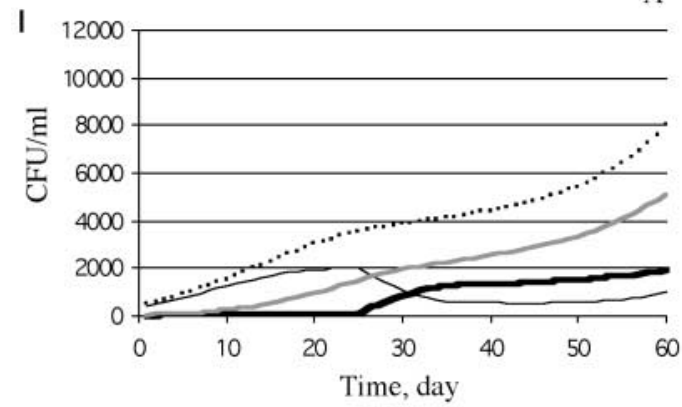

A

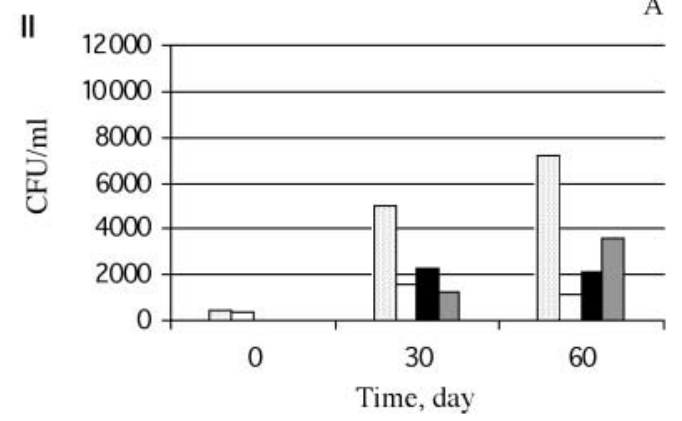

B

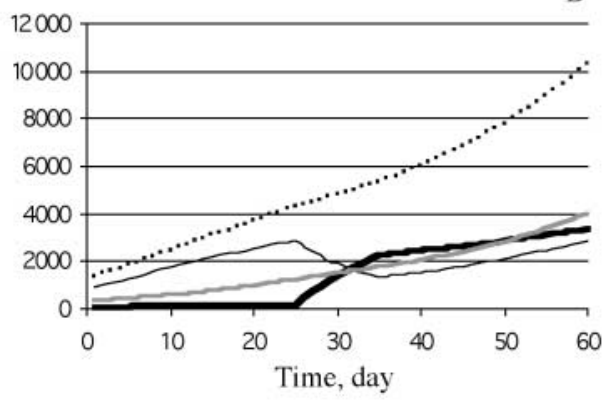

B

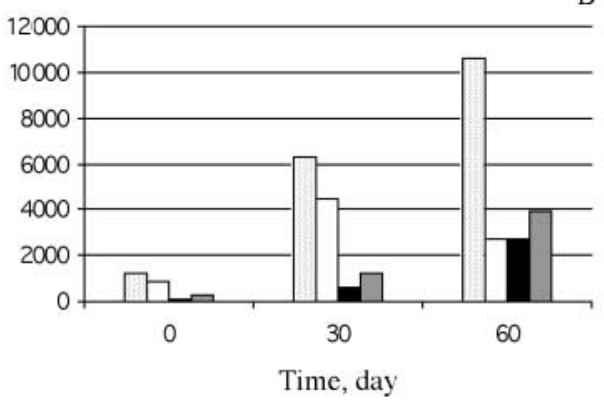

Fig. 5. Dynamics of antibiotic resistance of freshwater and halophile heterotrophic bacteria in a central part of Shira lake. Comparison of experimental data and model results: I—-model data, II—natural data; A — halophile bacteria, B—freshwater bacteria; dotted line(I) and light gray bar (II) — total number of bacteria, thin black line (I) and white bar (II) — bacteria sensitive to antibiotics, thick black line (I) and black bar (II) — bacteria resistant to ampicillin and kanamycin, gray line (I) and dark gray bar (II) — bacteria resistant to ampicillin 
where $t$ is the dynamic time, $t=0$ at start of season, $F_{1}$ is the transfer rate of bacteria to community $X_{2}$ under the anthropogenic impact and $F_{2}$ is the transfer rate of bacteria to community $X_{3}$ under the natural impact; $B_{1}$ is the rate at which bacteria lose their multiple antibiotic resistance and $B_{2}$ is the rate at which bacteria lose their ampicillin resistance; $\mu_{1}$ is the specific growth rate of $X_{1}, \mu_{2}$ is the specific growth rate of $X_{2}$ and $\mu_{3}$ is the specific growth rate of $X_{3} ; \varepsilon_{1}$ is the specific death rate of $X_{1}, \varepsilon_{2}$ is the specific death rate of $X_{2}$ and $\varepsilon_{3}$ is the specific death rate of $X_{3} ; b_{1}$ is the degradation rate coefficient for $X_{2}$ and $b_{2}$ is the degradation rate coefficient for $X_{3 i} k_{F_{1}}$ is the action rate coefficient of the anthropogenic factor; $A$ is the maximum intensity of the natural factor action; and $C$ is the time when the value of the natural factor action is equal to half of its maximal intensity.

We do not know the real pattern of development of heterotrophic bacteria in the lake. That is why the specific growth rates were defined by the approximation of the experimental data. For freshwater bacteria $\mu(t)=$ $-7 \times 10^{-7} t^{3}+10^{-4} t^{2}-0.0045 t+0.0895$, and for halophile bacteria $\mu(t)=-10^{-06} t^{3}+0.0002 t^{2}-0.0107 t+0.1874$. We chose the following values for the parameters involved in the model calculation: $t_{1}=25 \mathrm{~d}, t_{2}=35 \mathrm{~d}$, $\varepsilon_{1}=0.01 \mathrm{~d}^{-1}, \varepsilon_{2}=0.01 \mathrm{~d}^{-1}, \varepsilon_{3}=0.01 \mathrm{~d}^{-1}, b_{1}=0.4 \mathrm{~d}^{-1}, b_{2}=$ $0.2 \mathrm{~d}^{-1} ; k_{F_{1}}=0.1$ and $A=0.15$. The initial values of the model variables corresponded to the field data obtained in June.

There is good relationship between the model and the experimental data on the dynamics of antibiotic resistance (Fig. 5) in halophile and freshwater bacteria from the central part of Shira lake. This may be treated as a confirmation of the above hypothesis about the reasons underlying antibiotic resistance of bacteria in the central part of the lake. To validate this hypothesis, experimental investigations should be conducted to estimate the influence of algae on the ampicillin resistance of heterotrophic bacteria in the period of phytoplankton development.

Acknowledgements. This work was supported by Krasnoyarsk Region Scientific Foundation No. 228, Russian Foundation for Basic Research Nos. 01-05-64615 and MAC 02-0506250.

\section{LITERATURE CITED}

Backhaus T, Grimme LH (1999) The toxicity of antibiotic agents to the luminescent bacterium Vibrio fischeri. Chemosphere 38(14):3291-3301

Bernard L, Schafer H, Joux F, Courties C, Muyzer G, Lebaron P (2000) Genetic diversity of total, active and culturable halophile bacteria in coastal seawater. Aquat Microb Ecol 23:1-11

Boyandin AN, Lobova TI, Krylova TYu, Kargatova TV, Popova LYu, Pechurkin NS (2000) The salinity factor and adaptability of recombinant microorganisms Escherichia coli and Bacillus subtilis. Mikrobiologiya 69(2):243-247

Chandrasekaran S, Venkatesh B, Lalithakumari D (1998) Transfer and expression of multiple antibiotic resistance plasmid in marine bacteria. Curr Microbiol 37:347-351

Doust JL, Schmidt M, Doust LL (1994) Biological assessment of aquatic pollution: a review, with emphasis on plants as biomonitors. Biol Rev Camb Phil Soc 69(2):147-186

Doucette GJ (1995) Interaction between bacteria and harmful algae: a review. Nat Toxins 3(2):65-74

Gomes-Lus R (1998) Evolution of bacterial resistance to antibiotics during the last three decades. Int Microbiol 1: 279-284

Goni-Urriza M, Capdepuy M, Arpin C, Raymond N, Caumette C, Quentin C (2000) Impact of an urban effluent on antibiotic resistance of riverine Enterobacteriaceae and Aeromonas spp. Appl Environ Microbiol 1:125-132

Guardabassi L, Petersen A, Olsen JE, Dalsgaard A (1998) Antibiotic resistance in Acinetobacter spp. isolated from sewers receiving waste effluent from a hospital and pharmaceutical plant. Appl Environ Microbiol 9:3499-3502

Hagedorn C, Robinson SL, Filtz JF, Grubbs SM, Angier TA, Raymond B, Reneau RB Jr (1999) Determining sources of fecal pollution in rural Virginia watershed with antibiotic resistance patterns in fecal Streptococci. Appl Environ Microbiol 65(12):5522-5531

Ho MW, Traavik T, Olsvik T, Tappeser B, Howard CV, Von Weizsacker C, McGavin GC (1998) Gene technology and gene ecology of infections disease. Microbiol Ecol Health Dis 10:3-11

Hound T, Ochman H (2000) Long-term shifts in patterns of antibiotic resistance in enteric bacteria. Appl Environ Microbiol 66(12):5406-5409

Jacobs MJ, Tynkkynen S, Sibacov M (1995) Highly bioluminescent Streptococcus thermophilius strain for the detection of dairy-relevant antibiotics in milk. Appl Microbiol Biotechnol 44:405-412

Kalacheva GS, Gubanov VG, Gribovskaya IV, Gladchenko IA, Zinenko GK, Savitsky SV (2002) Chemical analysis of Shira lake water (1997-2000). Aquat Ecol 36(2):123-141

Kurlov MT (1927) Lake Shira resort. Kr.znamya, Tomsk (in Russian)

Lemke MJ, Leff LG (2000) Bacterial populations in an anthropogenically disturbed stream: comparison of different seasons. Microb Ecol 38 (3):234-243

Lenski RE (1998) Bacterial evolution and the cost of antibiotic resistance. Int Microb 1:265-270

Lindstron-Seppa P, Urban K, Honkaampi-Hamalainen U, Roy $S$ (2001) Biochemical responses in aquatic plants as markers of environmental contamination. Altern Lab Anim 29(3):277-282

Lobova TI, Boyandin A, Popova L (2000) Natural and anthropogenic impacts on plasmid fixture in the microbial link of Shira lake ecosystem. In: Kolchanov NA, Fedotov AM (eds) Biodiversity and dynamics of ecosystems in North Eurasia, Vol 5. IC\&G, Novosibirsk, p 16-18

Lobova TI, Popova LYu, Maksimova EE (2001) Geographical and seasonal distribution of multiple antibiotic resistance of heterotrophic bacteria of Shira lake. Aquat Ecol 36(2):299-307

Mary P, Defives C, Hornez JP (2000) Occurrence and multiple antibiotic resistance profiles of non-fermentative gramnegative microflora in five brands of non-carbonated french bottled spring water. Microb Ecol 39(4):322-329

McArthur JV, Tuckfield RC (2000) Spatial patterns in antibiotic resistance among stream bacteria: effect of industrial pollution. Appl Environ Microbiol 9:3722-3726 
Miller JH (1972) Experiments in molecular genetics. Society of Fellows, Harvard University and Département de Biologie Moleculaire, Université de Genève, Cold Spring Harbor Lab, Cold Spring Harbor, NY

Ostroumov SA (2000) A conception of aquatic biota as a labile and vulnerable component of the water self-purification system. Doclady Akademii Nauk 372(2):279-282

Parnachev VP, Vishnivetsky II (1997) On the specialized program aimed to rehabilitate the environmental conditions in the natural complex 'Shira Lake'. In: Parnachev VP (ed) Mediko-biologicheskiye i ekologicheskiye problemy kurortnogo kompleksa ozera Shira (Biomedical and ecological problems of the Shira lake resort). Tomsk University Publishers, Tomsk, p 114-124

Samecka-Cymerman A, Kempers AJ (2001) Bioindication of heavy metals with aquatic macrophytes: the case of a stream polluted with power plant sewages in Poland. Toxicol Environ Health 62(1):57-67

Schwedt G, Reiter C, Uthemann R, Grabert E (1997) Development of an automated bacterial luminescence test for biomonitoring of environmental contaminants Fresenius J Anal Chem 359:155-160

Editorial responsibility: Jed Fuhrman,

Los Angeles, California, USA
Simon M, Glockner FO, Amann R (1999) Different community structure and temperature optima of heterotrophic picoplankton in various regions of the Southern Ocean. Appl Environ Microbiol 18:275-284

Sommaruga R, Conde D (1997) Seasonal variability of metabolically active bacterioplankton in the euphotic zone of a hypertrophic lake. Aquat Microb Ecol 13:241-248

Ventosa A, Nieto JJ, Oren A (1998) Biology of moderately halophilic aerobic bacteria. Microbiol Mol Biol Rev 62: $504-544$

Yang Y, Yao J, Hu S, Qi Y (2000) Effect of agricultural chemicals on DNA sequence diversity of soil microbial community: a study with RAPD marker. Microb Ecol 39(1):72-79

Zhongtang Yu, Stewart GR, Mohn WW (2000) Apparent contradiction: psychrotolerant bacteria from hydrocarboncontaminated Arctic tundra soils that degrade diterpenoids synthesized by trees. Appl Environ Microbiol 66(12):5148-5154

Zotina TA, Tolomeev AP, Degermendzhy NN (1999) Lake Shira, a Siberian salt lake: ecosystem structure and function. 1: Major physico-chemical and features. Intern J Salt Lake Res 8:211-232

Submitted: August 17, 2001; Accepted: June 26, 2002 Proofs received from author(s): November 1, 2002 